\title{
HEDONIC AND UTILITARIAN DRIVERS OF CUSTOMER ENGAGEMENT
}

\section{Żyminkowska, K.}

Although the notion of customer engagement has been an important topic of ongoing discussion in marketing academia and business practice, still little is known on the impact of customer value that comprises of hedonic and utilitarian dimensions, on customer behavioral manifestations toward the brands or firms that goes beyond purchase. The main purpose of this study is to examine whether and how hedonic and utilitarian dimensions of customer value impact customer engagement across distinct consumer markets. Based on the computer-assisted web interviews with 1,559 consumers in the age of 15-64, descriptive statistics and structural equation modelling are used in this study. Consumers of three distinct product categories such as clothing, beer, and mobile phones are interviewed. Drawing on the behavioral interpretation of customer engagement and means-ends models of customer value, this paper reveals the crucial impact of hedonic and utilitarian values on customer engagement manifested in three forms such as customers' communication, customer complaints and customer collaboration, offering the holistic perspective on multi-faced nature of customer engagement. The research also uncovers some disparities in the strength of the hedonic and utilitarian drivers of customer engagement across markets. Thus, the current study contributes to the better understanding of the customer-based factors affecting customer engagement and offers managerial implications on designing the effective sets of incentives for mobilizing customer engagement.

Keywords: customer value, customer engagement, customer engagement behavior, hedonic values, utilitarian values

JEL Classification: M31

\section{Introduction}

Customer value (CV), often termed as customer perceived value, is considered to be one of the central constructs in contemporary marketing, a fundament for its processual definitions (AMA, 2004-2017). Means-ends model envisages CV in terms of the customer acquiring and using a firms' offerings to accomplish favorable and predefined ends, i.e. personal values (Khalifa, 2004; Huber et al., 2001), consisted of hedonic and utilitarian elements 
(Heinonen et al., 2013; Babin et al., 1994). Customer engagement (CE), on the other hand, is an emerging concept with the conceptual foundations grounded in relationship marketing and service-dominant logic in marketing (Brodie et al., 2011). In its behavioral interpretation $\mathrm{CE}$ goes beyond purchase and is a behavioral manifestation toward the brand or firm (offerings and activities), often involving others in the social network created around the brand, offering or activity (Verhoef et al., 2010; Vivek et al., 2014).

Although there is a stream in literature already working on the value of CE to the firm (Kumar et al., 2010; Kumar \& Pansari, 2016; Pansari \& Kumar, 2017), still little is known regarding the value of engagement for customers. Scholarly insights into the nature of $\mathrm{CE}$ and CV relationship are still rare. Most of the studies don't encompass the multi-faced nature of $\mathrm{CE}$ in exploring $\mathrm{CE}$ and $\mathrm{CV}$ relationship, focusing rather on its certain forms in isolation (Muntinga et al., 2011; Abrantes et al., 2013; Fernandes \& Remehle, 2016). Few studies offer the holistic approach (Marbach et al., 2016; Groeger et al., 2016; Verhagen et al., 2015; Jaakkola \& Alexander, 2014) contributing to the understanding the CV and CE interface, however most of this research doesn't refer to the behavioral interpretation of CE. Besides, existing studies focus on engagement towards a given brand or market overlooking the potential disparities in the impact of value drivers on $\mathrm{CE}$ across distinct markets or product categories.

Addressing the identified research gaps, this paper aims to explore the following research questions. First, does hedonic and utilitarian value dimensions influence customer engagement? Second, what value dimension (hedonic or utilitarian) is a stronger driver for customer engagement? And third, are there any disparities regarding the impact of hedonic and utilitarian values on customer engagement across distinct consumer markets? Based on the quantitative research of a large sample of 2,080 consumers across distinct product categories, this study explores the impact of hedonic and utilitarian values on CE making contributions to theory and practice. The paper is structured as follows. First, the theoretical background that underpins the relationships in the study is presented. In the next sections, the research methodology is discussed followed by the analysis of the results. The paper concludes with the implications for academic and practitioners, the study limitations and future research directions.

\section{Conceptual Background}

\subsection{Forms of customer engagement}

Various approaches have already evolved while interpreting customer engagement in marketing discipline. Two main perspectives may be distinguished among existing CE interpretations. First perspective refers to the attitudinal and multidimensional understanding of $\mathrm{CE}$ while the second one indicates one-dimensional, behavioral $\mathrm{CE}$ clarification. $\mathrm{CE}$, in an attitudinal interpretation, is a psychological state that occurs by virtue of interactive, cocreative customer experiences with a focal agent/object (e.g., a brand) in focal service 
relationships. It is a multidimensional concept subject to a context- and/or stakeholderspecific expression of relevant cognitive, emotional and/or behavioral dimensions (Brodie et al., 2011). Engaged individuals include current as well as prospective customers (Vivek et al., 2014). In a behavioral, one-dimensional interpretation, often named as customer engagement behavior, CE stands for customer's behavioral manifestations toward a brand or firm, that have a brand or firm focus, beyond purchase, resulting from motivational drivers (van Doorn et al., 2010; Verhoef et al., 2010; Beckers et al., 2016). In this one-dimensional perspective, CE is also defined as customer's voluntary resource contribution to a firm's marketing function that goes beyond financial patronage (Harmeling et al., 2017).

In the second, behavioral research stream on $\mathrm{CE}$, the literature distinguishes different forms/types of customers' behavioral manifestations beyond purchase, including word-ofmouth (WOM) activity, recommendations, helping other customers, blogging, writing reviews, engaging in legal action, feedback, or suggestions for new products ideas (van Doorn et al., 2010). Jaakkola and Alexander (2014) identify two general types of customer engagement behaviors in previous literature. The first is customer involvement in product development and innovation and signifies that customers help to improve or develop the firm's offerings by providing feedback, ideas, and information, or participating in product design or assembly. The second one, customers' communication about the focal firm or brand implies that customer may acquire new customers for the firm through firmincentivized referral programs or influence other customers' perceptions on their own initiative through word-of-mouth, blogging and other forms of customer-to-customer interactions. Verleye et al. (2014) distinguish five forms of customer engagement behaviors. These are: cooperation (customers' benevolent act to help employees to do their work), feedback (giving feedback to the firm and its employees via suggestions for service improvements or through participation in new product and service development processes), compliance (the degree to which customers comply with organizational rules and procedures), helping other customers (by expressing empathy, encouraging each other to show appropriate behaviors, helping each other to get better service experiences), and spreading positive WOM or recommending the firm to other customers.

Some other typologies also list co co-creation among CE forms (Bijmolt et al., 2010; Beckers et al., 2016), however, in this study, we don't' support this approach because of two main reasons. First, co-creation of value is rather higher order construct and is neither normative nor optional (Vargo \& Lusch, 2008, Vargo, 2008), so each CE form may be the manifestation of value co-creation. Second, $\mathrm{CE}$ is associated with the integration of customers' resources into the firms' business processes. Customers make voluntary resource contributions that have a brand or firm focus but go beyond what is fundamental to transactions (Harmeling et al., 2017; Jaakkola \& Alexander, 2014). As such, integrating those resources in value creation (both for firms and for customers) may be associated with risk of misuses of resources (Plé \& Chumpitaz Cáceres, 2010) and lead to the value codestruction instead of co-creation (Echeverri \& Skålén, 2011), both in terms of customer- 
level value (i.e. customer value) (Groeger et al., 2016), and firm-level value (i.e. customer equity, firm value) (Beckers et al., 2018).

Therefore, in the current research, drawing on the findings of the review of existing $\mathrm{CE}$ typologies, we explore the impact of hedonic and utilitarian drivers on CE manifested in the three following forms. First, customers' communication (i.e. customer-to customer communication) that refers to word of mouth (both positive and negative), and helping others, that occurs in customer-to-customer interactions. Second, customer complaints that are kind of customer feedback occurring within customer to firm (or other institutions as media or consumer right advisor) interactions, however they are driven by customer dissatisfaction. And third, customer collaboration, that also occurs in customer to firm interactions, and includes providing feedback, ideas, and information (i.e. customer knowledge), or performing some tasks providing customer skills, e.g. in product design or assembly.

\subsection{Customer value dimensions}

Although the concept of customer value (CV) has dynamically evolved in marketing literature, there is a general agreement that it is subjectively defined by a customer, not a supplier (Khalifa, 2004). Therefore, it is also labelled as customer perceived value. Two aspects of the evolution of this category are essential to the current research: broadening dimensionality of customer value interpretations and changing logic of customer value measurement reflected in the CV models.

Regarding the customer value dimensions, this construct was originally understood as something tangible, packed in the product (Baggozzi, 1975; Khalifa, 2004; Heinonen et al., 2013). Later conceptualizations of customer value, within the relationship marketing, introduced some intangible dimensions too. For instance, Kotler and Armstrong (2016) list four determinants of customer perceived value associated with the benefits contained in product, services, personnel and firm/brand image. Finally, the phenomenon of customer experiences was emphasized in the customer value definition based on Holbrook (1999) view, according to which value is interactive, relativistic, experiential, and preferential (Talonen et al., 2016). Customer perceived value is then characterized as a customer experience (Helkkula et al., 2012; Vargo \& Lusch, 2017). Furthermore, customer value is formed in various visible and invisible experiential spaces (e.g., social, virtual, mental, biological, physical) that reflect the customer's ecosystem and life sphere (Heinonen et al., 2013). Therefore, the understanding of customer value as value-in-social-context was suggested to reflect the variety of actors who may be involved in value creation (Edvardsson et al., 2011; Saarijärvi et al., 2013; Vargo \& Lusch, 2017). Consequently, there are four customer value dimensions recognized in recent marketing literature (Sánchez-Fernández \& Ángeles, 2007; Talonen et al., 2016). First, economic value such as money savings, value for money, finding the lowest price or the best trade-off between price and quality. Second, functional value consisted of quality, convenience, quality/performance, or finding the right time at the right place. Third, emotional and experiential value that comprises exploration, 
entertainment, aesthetics, playfulness, escapism, enjoyment, or pleasure, and the emotional experience. Fourth, symbolic and social value referring to status, self-esteem, and selfexpression. In more synthesized proposition of customer value dimensions it is conceptualized as a set of tangible (utilitarian) and intangible (hedonic) elements (Heinonen et al., 2013; Babin et al., 1994). Utilitarian dimension includes economic and functional values, while hedonic dimension comprises of emotional and experiential as well as symbolic and social values (Talonen et al., 2016). Those two main value dimensions are explored in this study, and its impact on CE is recognized.

Concerning the measurement approaches to customer value, the second aspect of the evolution in the CV interpretation, and three customer value models may be distinguished, as proposed by Khalifa (2004). First, value components models that focus on customer benefits and demote the customer's sacrifice side of the value equation. Second, benefits/costs ratio models, consider customer value as the difference between the customer's evaluation of all the benefits (positive consequences) and costs (negative consequences / sacrifices / costs) of an offering and the perceived alternatives (competing offers) (Kotler \& Armstrong, 2016). Those models are broader than the value components and more complete, but they do not address the problem of importance of various benefits and the significance of sacrifices in the context of customer behavior. This problem is emphasized within the third, means-ends models, of customer value. Those models envisage customer value in terms of the customer acquiring and using a firms' offerings to accomplish favorable and predefined ends, i.e. personal values (Khalifa, 2004; Huber et al., 2001), so they focus on customer benefits while failing to pay attention to the customer sacrifices. According to means-ends models of customer value, customers choose actions that produce desired consequences and minimize undesired ones and thus personal values provide the overall direction, and consequences determine the selection of behavior (Peter \& Olson, 1990). Therefore, based on those models (e.g., Wudruff \& Gardial, 1996) the favorable ends (i.e. customer's goals and purposes) may be identified in terms of personal values arising from engagement. Personal or consumption values consist of functional, social, emotional, epistemic and conditional elements (Sheth et al., 1991) that reflect abovementioned multidimensional character of customer value. Adopting a means-ends customer value hierarchy model (Woodruff \& Gardial, 1996) in this paper we attempt to explain what the favorable ends are (i.e. customer's goals and purposes) in terms of personal values that are desired by customers from their engagement, and, at the same time, provide the overall direction of customer behavioral manifestation beyond purchase.

\subsection{Customer value dimensions and customer engagement linkages}

In previously developed theoretical models of customer engagement, customer value is perceived as one of the CE antecedents (van Doorn et al., 2010), or as both antecedent and consequence of CE (Vivek et al., 2012). This dual perspective on the linkages between customer value and customer engagement, i.e. value drives engagement vs. value results 
from engagement, is reflected in subsequent conceptual and empirical studies. The first research stream explores customer value dimensions as customer engagement effects. Based on Holbrook (1999), Marbach et al. (2016) recognize hedonic perceived values of online customer engagement, namely social, play, excellence, efficiency, aesthetic value and altruistic value. Based on the results of qualitative study, Groeger et al. (2016) identify both hedonic and utilitarian dimensions of value from engagement behaviors for non-paying consumers such as free trials and premiums for campaign participation, enhanced knowledge/experience, brand/product self-identification, recognition, and curated/filtered exposure. Besides, by drawing on qualitative research results, Hollebeek (2013) identifies a curvilinear association between $\mathrm{CE}$ and ensuing $\mathrm{CV}$ perceptions, and further finds that $\mathrm{CE}$ generates greater $\mathrm{CV}$ increases for hedonic, than for utilitarian brands.

On the other hand, second research stream on CE and CV linkages, explores customer value dimensions as the drivers of customer engagement (or its certain forms). Verhagen et al. (2015) recognize the determinants of CE intentions in virtual customer environment such as: cognitive benefits (access to knowledge, feedback), social integrative benefits (social identification, social ties), personal integrative benefits (peer recognition, company recognition), and hedonic benefits (self-expression, altruism). Regarding customers' communication, one of the CE forms, Abrantes et al. (2013) uncover the following hedonic drivers of word of mouth: mood enhancement, escapism, experiential learning, and social interaction. Previous studies also examined the drivers of the second form of CE - customer collaboration. Motivation sources of virtual customer integration in the innovation process recognized by Rohrbeck et al. (2010) consist of both utilitarian and hedonic values, i.e. monetary incentives, product usage and personal needs, social recognition, and entertainment and curiosity. Similar values were examined regarding motivations for participating in innovation and product development communities (Shah, 2004), including need for product, enjoyment, desire to create and improve, reputation and status within community, affiliation, identity, values, ideology, learning, reputation outside the community, and career concerns. Füller et al. (2010) confirmed the following customer motivations to engage in virtual customer integration projects in product development: compensation, interest in innovation, help and product improvement.

The abovementioned duality of research on the linkages between customer value and customer engagement, and perceiving $\mathrm{CV}$ as $\mathrm{CE}$ antecedent or/and CE consequence, seem to reflect the assumptions of means-ends model. Customers engage to accomplish their favorable and predefined ends (personal values) (Khalifa, 2004). Therefore, CE results in capturing certain customer value, and customer hedonic and utilitarian values may be understood as CE consequences. On the other hand, drawing on means-ends model, customers choose actions that produce desired consequences and minimize undesired ones and thus personal values provide the overall direction of behavior - customer engagement. Therefore, expected and desired customer values may direct customer behavior (his/her engagement), and in that case those values are $\mathrm{CE}$ antecedents. 


\section{Methods}

In order to uncover the linkages between hedonic and utilitarian values and customer engagement we conducted a quantitative research among Polish consumers. To uncover possible disparities regarding the customer value impact on $\mathrm{CE}$ among distinct markets, three product categories were selected from the FCB grid (Vaughn, 1986; Ratchford, 1987; Lambin, 1998) and determined the samples selection. These are the categories that differ across the level of customer involvement (high vs. low) and the type of the mode of information processing (cognitive / thinking vs. affective / feeling). Customer involvement is perceived as an antecedent of CE (Vivek et al., 2012; Hollebeek et al., 2014). Customer involvement with products leads to greater perception of attribute differences, perception of greater product importance, and greater commitment to brand choice (Howard \& Sheth, 1969; Zaichkowsky, 1985). Therefore, the consumers of the following products were surveyed: clothing (high involvement feeling product category), beer (low involvement feeling category), and mobile phones (high involvement thinking product). Customer engagement focused on the brands, products or firms' activities offering those product categories was investigated as well as its hedonic and utilitarian drivers.

The sampling framework was stratified by gender and age to represent the Polish population structure in the age of 15-64. The respondents were recruited from the IMAS OnLine research panel, consisted of 44,500 participants, representing the Polish nationwide population according to the age. The computer-assisted web interviewing (CAWI) was used to collect data between August 23 and September 13, 2017. 8,968 e-mail invitations were sent, and 1,559 respondents completed the questionnaire (17\%). The following CAWI rates were recorded: participation rate of $27 \%$, incidence rate of $68 \%$, and drop-out rate of $7 \%$. The average interview took 9 minutes and 10 seconds.

To measure hedonic and utilitarian dimensions of customer value and its impact on customer engagement we followed its previous conceptualizations and adopted a set of items from existing studies. Appendix provides an overview of the research variables and items. A pretest with 101 respondents was conducted to evaluate the reliability of the concepts before the final survey and to check the validity of the questionnaire. After the pretest a few modifications were made to obtain higher quality of analysis later. To operationalize the items, 5-point Likert scales were used. To analyze the dataset the structural equation modelling (SEM) was used as the proper method of not only used as a confirmatory factor analysis (CFA) but also a way to identify the relation with other constructs (via regression modelling). We used Mplus (version 8) for the analysis (Muthén \& Muthén, 2017). We assessed the validity and reliability of the measurement model (see Table 1). 
Table 1 | Validity and reliability statistics

\begin{tabular}{|l|r|r|r|}
\hline \multicolumn{1}{|c|}{ Latent variable } & \multicolumn{1}{|c|}{$\begin{array}{c}\text { Average } \\
\text { Variance } \\
\text { Extracted (AVE) }\end{array}$} & $\begin{array}{c}\text { Composite } \\
\text { reliability } \\
\text { (CR) }\end{array}$ & $\begin{array}{c}\text { Cronbach's } \\
\text { Alpha }\end{array}$ \\
\hline Customers' communication & 0.638 & 0.876 & 0.838 \\
\hline Customer complaints & 0.588 & 0.850 & 0.810 \\
\hline Customer collaboration & 0.633 & 0.873 & 0.813 \\
\hline Hedonic customer value dimension & 0.701 & 0.875 & 0.846 \\
\hline Utilitarian customer value dimension & 0.646 & 0.846 & 0.797 \\
\hline
\end{tabular}

We supported the convergent validity of the measures as all standardized factor loadings and average variances extracted (AVE) surpassed the value of 0.50 (MacKenzie et al., 2011) and all composite reliability scores exceeded the recommended value of 0.70 (Hair et al., 2010). All scales internal reliability is significant: all constructs present also the Cronbach Alphas above the recommended values of 0.70 (Nunnally, 1978). We estimated the structural equation model for total sample (see Figure 1) as well as for the separate models for each product category tested under study. The fit indices for main model (CFI=0.97, TLI=0.98 and RMSEA=0.049 with $90 \%$ of $\mathrm{CI}-0.046-0.051$ ) reveal that its fit is quite good (Bentler, 1990; Tucker \& Lewis, 1973; Steiger, 1990). Also, the fit of each three models for product categories is acceptable.

\section{Results}

\subsection{Descriptive statistics}

Respondents declared how important are hedonic and utilitarian values for mobilizing their engagement focused on brands or firms' offerings or activities across three consumer markets. According to the opinions of 1,559 surveyed consumers, the utilitarian values were quite important motivations for their engagement: mean close to 4.0 implies that respondents considered those values as rather important. On the other hand, hedonic values turned to be neutral for surveyed respondents' engagement since the average was close to 3.0 on 5-point Likert scale (see Table 2).

In the respondents' opinion, getting a better product was the most important utilitarian value in each consumer market under study, i.e. clothing, beer, and mobile phones. On the other hand, joining the consumer communities was the least important hedonic value for customers. Regarding the cross-market comparisons, beers consumers perceive both hedonic and utilitarian values as slightly more important reason of their engagement than the consumers of the remaining product categories. 
Table 2 | The importance of customer value dimensions in driving customer engagement

\begin{tabular}{|l|l|r|r|r|r|}
\hline $\begin{array}{l}\text { Customer } \\
\text { value } \\
\text { dimensions }\end{array}$ & \multicolumn{1}{|c|}{ Items } & $\begin{array}{c}\text { Total } \\
\text { Sample } \\
(\mathbf{n = 1 , 5 5 9 )}\end{array}$ & $\begin{array}{c}\text { Clothing } \\
(\mathbf{n = 5 2 1})\end{array}$ & \multicolumn{1}{c|}{$\begin{array}{c}\text { Beer } \\
(\mathbf{n = 5 2 0})\end{array}$} & $\begin{array}{c}\text { Mobile } \\
\text { phones } \\
(\mathbf{n = 5 1 8})\end{array}$ \\
\hline \multirow{5}{*}{ Hedonic } & $\begin{array}{l}\text { Making contacts with } \\
\text { other users }\end{array}$ & $\mathbf{3 . 2}$ & 3.1 & 3.3 & 3.2 \\
\cline { 2 - 6 } & $\begin{array}{l}\text { Joining the consumer } \\
\text { communities (e.g. brand } \\
\text { fans) }\end{array}$ & $\mathbf{3 . 0}$ & 3.0 & 3.1 & 3.0 \\
\cline { 2 - 6 } & $\begin{array}{l}\text { Being respected by others } \\
\text { (peers, users) }\end{array}$ & $\mathbf{3 . 2}$ & 3.2 & 3.3 & 3.2 \\
\cline { 2 - 6 } & Total & $\mathbf{3 . 1 3}$ & $\mathbf{3 . 1 0}$ & $\mathbf{3 . 2 3}$ & $\mathbf{3 . 1 3}$ \\
\hline \multirow{3}{*}{ Utilitarian } & Getting a better product & $\mathbf{4 . 0}$ & 4.0 & 4.1 & 4.1 \\
\cline { 2 - 7 } & $\begin{array}{l}\text { Receiving discounts for } \\
\text { next shopping }\end{array}$ & $\mathbf{4 . 0}$ & 4.0 & 4.0 & 4.0 \\
\cline { 2 - 7 } & $\begin{array}{l}\text { Receiving the material } \\
\text { reward }\end{array}$ & $\mathbf{3 . 8}$ & 3.7 & 3.9 & 3.8 \\
\cline { 2 - 7 } & Total & $\mathbf{3 . 9 3}$ & $\mathbf{3 . 9 0}$ & $\mathbf{4 . 0 0}$ & $\mathbf{3 . 9 7}$ \\
\hline
\end{tabular}

\subsection{Structural model}

The empirical results of this study lead to the following findings. First, taking the entire model structure into consideration, the analyses provide strong and robust support for the close linkage between hedonic and utilitarian dimensions of customer value and customer engagement manifested by its three forms: customers' communication, customer complaints and collaboration (see Figure 1). Those effects are quite strong for customers' communication and customer collaboration $(0.91, p<0.01$ and $0.92, p<0.01$ respectively), and strong for customer complaints $(0.57, p<0.01)$. 


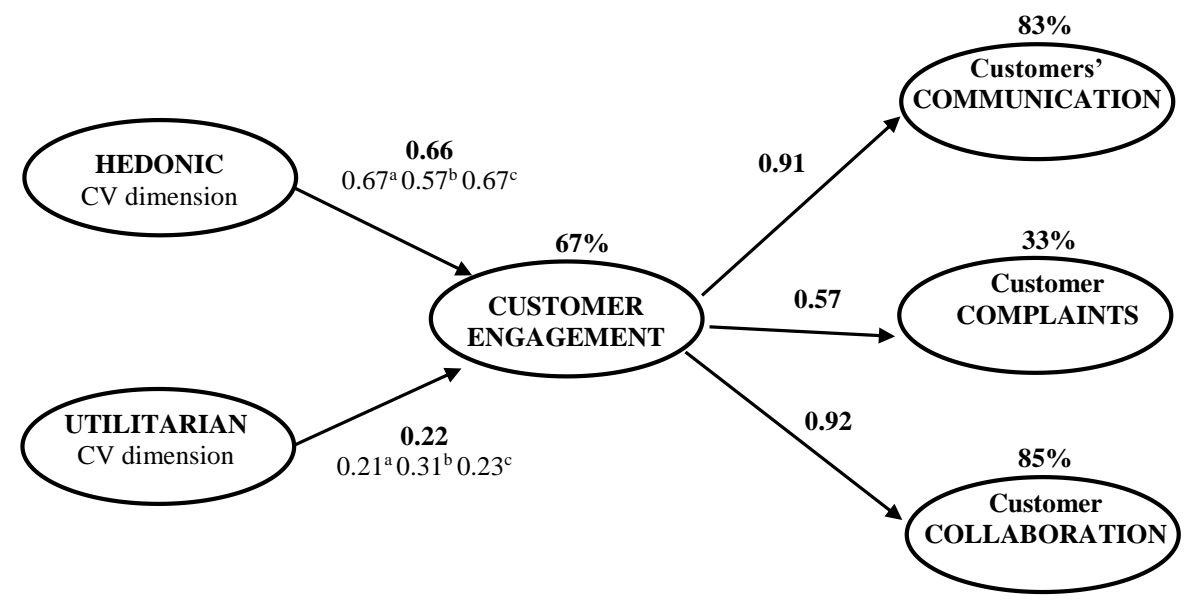

Note: $\mathrm{a}=$ clothing, $\mathrm{b}=$ beer, $\mathrm{c}=$ mobile phones.

Second, our results indicate that hedonic dimension of $\mathrm{CV}$ has a highly positive direct impact on $\mathrm{CE}(0.66, p<0.01)$, and utilitarian dimension of $\mathrm{CV}$ influences $\mathrm{CE}$ positively, although the impact is a bit weaker $(0.22, p<0.01)$. The percentage of variance in CE explained by the antecedents (hedonic and utilitarian CV dimensions) is 67\%. Third, the impact of hedonic dimension of $\mathrm{CV}$ on $\mathrm{CE}$ is higher than the impact of utilitarian dimension in each product category tested under the study. However, in case of clothing and mobile phones (examples of high-involvement product categories) it is more evident $(0.67, p<0.01)$ than in case of beer $(0.57, p<0.01)$. Fourth, concerning the interface of utilitarian dimension of $\mathrm{CV}$ and $\mathrm{CE}$, the impact is stronger in low-involvement product category as beer $(0.31, p<$ $0.01)$, than in clothing $(0.21, p<0.01)$ and mobile phones $(0.23, p<0.01)$.

\section{Discussion}

In this paper we offer cross-market recognition of the impact of hedonic and utilitarian customer values on customer engagement manifested in the three following forms: customers' communication, customer complaints, and customer collaboration. By positioning CE in the means-ends customer value hierarchy model (Woodruff \& Gardial, 1996) we explain what the favorable ends are (i.e. customer's goals and purposes) arising from engagement, that drive customer behavioral manifestations other than purchase (i.e. customer engagement in behavioral interpretation). The present findings provide both theoretical and managerial implications that are discussed in this section.

Based on the research results addressing first research question of this study it was revealed that both hedonic and utilitarian values were important drivers of customer engagement. Those customer motivations explained quite significant proportion of CE variance (65\%). We highlighted also that the linkage is stronger for customer collaboration with the brand or 
firm in product development or innovation, and for customers' communication about firm or brand, than for customer complaints. In line with the recommendations in previous literature (Beckers et al., 2016), these findings offer holistic perspective, overarching the multi-faced nature of $\mathrm{CE}$ manifested in different customer behaviors beyond purchase, and thus contribute to the better understanding of customer value impact on customer engagement forms.

Considering the second research question of this paper, our study showed that hedonic value dimension had stronger positive impact on $\mathrm{CE}$ than the utilitarian one, although the latter also positively influenced CE. Hence our empirical findings contribute to the development of the theory on customer engagement in its behavioral interpretation shedding light on customer-based factors affecting CE behaviors (as customer goals and perceived benefits) that are the element of van Doorn et al.'s (2010) conceptual model.

Referring to the third research question in this paper, our study brings both theoretical and managerial implications. Our research revealed that the crucial role of hedonic value dimension in producing customer engagement was evident across each product category under study (i.e. clothing, beer, and mobile phones). This implicates the directions for firms' endeavors within effective $\mathrm{CE}$ management and broaden the existing theory on $\mathrm{CE}$ management that urges to stimulate customer engagement by establishing set of incentives (van Doorn et al., 2010), and encourage customers' active participation in and contribution to the firm's marketing function (Harmeling et al., 2017). Our findings implicate that firms need to strongly address customer hedonic goals in order to mobilize customer engagement and offer attractive hedonic incentives to the customers they want to engage. Since our empirical results showed that utilitarian values also impacted $\mathrm{CE}$, firms need to develop specific set of engagement incentives, including hedonic encouragements (as major elements), that are completed with the utilitarian values. This study also revealed some differences in the strength of hedonic and utilitarian drivers across distinct product categories. The impact of hedonic value dimension was stronger for high-involvement product categories, such as clothing and mobile phones, than for low-involvement category such as beer. On the other hand, the strongest impact of utilitarian value dimension was recorded in beer category. This implicates the need for designing the sets of attractive incentives accordingly to mobilize customer engagement across distinct consumer markets. Firms need to adjust the proper proportions of hedonic and utilitarian incentives in distinct markets, for example to initiate the engagement of beer consumers slightly more utilitarian encouragements need to be offered than in case of clothing or mobile phones.

\section{Conclusion}

Drawing on the behavioral interpretation of customer engagement and means-ends models of customer value, this paper explores hedonic and utilitarian drivers of customer behavioral manifestations toward brands or firms' offerings and activities across three distinct consumer markets. Overarching the multi-faced nature of CE manifested in different forms 
of customer behaviors beyond purchase (i.e. customers' communication, customer complaints and customer collaboration), the current research provides insights on a vital role of customer values as drivers of customer engagement. Comparing the strength of utilitarian and hedonic values impact on customer engagement, this study also sheds light on customerbased factors affecting $\mathrm{CE}$ behaviors, indicating the vital role of hedonic values. Finally, this paper also reveals some differences in the strength of hedonic and utilitarian drivers across distinct product categories and highlights the need for adjusting incentives offered by firms in mobilizing customer engagement accordingly.

However, the paper is also subject to some limitations that provides the future research directions. First, research sample comprises only the inhabitants of Poland who may be representative for the Central and Eastern European countries but not the same trends could be found for all these countries to make generalization. Future studies could replicate this study across countries in which these analyses were not yet performed. Second, customer values that drive customer engagement are examined within two aggregated dimensions in the current research (i.e. hedonic and utilitarian values), although more detailed typologies indicate the existence of four distinct customer values. Utilitarian dimension encompasses economic and functional values, while hedonic dimension comprises of emotional and experiential as well as symbolic and social values. Then it could be examined in the further research whether the impact of detailed hedonic value dimensions, such as emotional \& experiential, and symbolic \& social values, is similar to the impact of hedonic dimension recognized in this paper, or there are any differences in that matter. Third, taking the entire model structure into consideration, this research provides support for the close linkage between hedonic and utilitarian dimensions of customer value and customer engagement manifested by its three forms, but those effects are quite stronger for customers' communication and customer collaboration than for customer complaints. Perhaps proposed structural model could be developed further to reflect examined relationships even better. And fourth potential limitation of the current study stems from the anchoring the customer engagement construct in the context of customer value reflected in the means-ends model. This model explains why customers attach different weights to various benefits of CE but fails to pay enough attention to the sacrifices a customer is likely to bear. It would be desirable if future studies would recognize such sacrifices in case of customer resource contributions during his/her engagement.

\section{Acknowledgement}

The research leading to the results discussed in the book has received funding from National Science Centre, Poland in project no 2014/13/B/HS4/01614. 


\section{References}

Abrantes, J. L., Seabra, C., Lages, C. R., \& Jayawardhena, C. (2013). Drivers of in-group and out-of-group electronic word-of-mouth (eWOM). European Journal of Marketing, 47(7), 1067-1088.

AMA (2018) Marketing Definition. Retrieved August 30, 2018 from https://www.ama.org/AboutAMA/Pages/Definition-of-Marketing.aspx.

AMA (2007). American Marketing Association, Information Memorandum. Retrieved $\begin{array}{llll}\text { December } & 30, & 2012 & \text { from }\end{array}$ http:/www.marketingpower.com/Community/ARC/Pages/Additional/Definition/def ault.aspx.

Babin, B. J., Darden, W. R., \& Griffin M. (1994). Work and/or Fun: Measuring Hedonic and Utilitarian Shopping. Journal of Consumer Research, 20(4), 644-656.

Baggozzi, R. P. (1975). Marketing as exchange. Journal of Marketing, 39(4), 32-39.

Beckers, S.F.M., van Doorn, J., \& Verhoef, P. C. (2016). Economic outcomes of customer engagement. Emerging finding, contemporary theoretical perspectives, and future challenges. In R. J. Brodie, L. Hollebeek, \& J. Conduit (Eds.), Customer Engagement. Contemporary issues and challenges (pp. 21-52). New York: Routledge.

Beckers, S. F., van Doorn, J., \& Verhoef, P. C. (2018). Good, better, engaged? The effect of company-initiated customer engagement behavior on shareholder value. Journal of the Academy of Marketing Science, 46(3), 366-383.

Bentler, P. M. (1990). Comparative fit indexes in structural models. Psychological Bulletin 107(2), 238-246.

Bijmolt, T. H., Leeflang, P. S., Block, F., Eisenbeis, M., Hardie, B. G., Lemmens, A., \& Saffert, P. (2010). Analytics for Customer Engagement. Journal of Service Research 13(3), 341-356.

Brodie, R., Hollebeek, L., Jurić, B., \& Ilić, A. (2011). Customer Engagement: Conceptual Domain, Fundamental Propositions, and Implications for Research. Journal of Service Research, 14(3), 252-271.

Echeverri, P., \& Skålén, P. (2011). Co-creation and co-destruction. A practice-theory based study of interactive value formation. Marketing Theory, 11(3), 351-373. 
Edvardsson, B., Tronvoll, B., \& Gruber, T. (2011). Expanding understanding of service exchange and value co-creation: A social construction approach. Journal of the Academy of Marketing Science, 39(2), 327-339.

Fernandes, T., \& Remelhe, P. (2016). How to engage customers in co-creation: customers' motivations for collaborative innovation. Journal of Strategic Marketing, 24(3-4), 311-326.

Füller, J., Faullant, R., \& Matzler, K. (2010). Triggers for virtual customer integration in the development of medical equipment from a manufacturer and a user's perspective. Industrial Marketing Management, 39(8), 1376-1383.

Groeger, L., Moroko, L., \& Hollebeek, L. D. (2016). Capturing value from non-paying consumers' engagement behaviours: field evidence and development of a theoretical model. Journal of Strategic Marketing, 24(3-4), 190-209.

Hair, J., Black, W., Babin, B., Anderson, R., \& Tatham, R. (2010). Multivariate Data Analysis, 7th ed. Harlow: Pearson.

Harmeling, C. M., Moffett, J. W., Arnold, M. J., \& Carlson, B. D. (2017). Toward a theory of customer engagement marketing. Journal of the Academy of Marketing Science, 45(3), 312-335.

Heinonen, K., Strandvik, T., \& Voima, P. (2013). Customer dominant value formation in service. European Business Review, 25(2), 104-123.

Helkkula, A., Kelleher, C., \& Pihlstrom, M. (2012). Characterizing value as an experience: Implications for service researchers and managers. Journal of Service Research, 15(1), 59-75.

Holbrook, M. (1999). Consumer value: A framework for analysis and research. Oxon: Routledge.

Hollebeek, L. D. (2013). The customer engagement/value interface: An exploratory investigation. Australasian Marketing Journal, 21(1), 17-24.

Hollebeek, L. D., Glynn, M. S., \& Brodie, R. J. (2014). Consumer brand engagement in social media: Conceptualization, scale development and validation. Journal of Interactive Marketing, 28(2), 149-165.

Howard, J. A., \& Sheth, J. N. (1969). The Theory of Buyer Behavior. New York: John Wiley.

Huber, F., Herrmann, A., \& Morgan, R. E. (2001). Gaining competitive advantage through customer value-oriented management. Journal of Consumer Marketing, 18(1), 4153. 
Jaakkola, E., \& Alexander, M. (2014). The Role of Customer Engagement Behavior in Value Co-Creation. A Service System Perspective. Journal of Service Research, 17(3), $247-$ 261.

Khalifa, A. S. (2004). Customer value: a review of recent literature and an integrative configuration. Management Decision, 42(5/6), 645-666.

Kotler, P., \& Armstrong, G. (2016). Principles of Marketing. 16th Global Edition. Edinburgh: Pearson Education Inc.

Kumar, V., Aksoy, L., Donkers, B., Venkatesan, R., Wiesel, T., \& Tillmanns, S. (2010). Undervalued or Overvalued Customers: Capturing Total Customer Engagement Value. Journal of Service Research, 13(3), 299-302.

Kumar, V., \& Pansari, A. (2016). Competitive Advantage through Engagement. Journal of Marketing Research, 53(4), 497-514.

Lambin, J.-J. (1998). Market-driven management. Strategic and operational marketing. New York: MacMillan Press.

MacKenzie, S. B., Podsakoff, P. M., \& Podsakoff, N. P. (2011). Construct measurement and validation procedures in MIS and behavioral research: Integrating new and existing techniques. MIS Quarterly, 35(2), 293-334.

Marbach, J., Lages, C. R., \& Nunan, D. (2016). Who are you and what do you value? Investigating the role of personality traits and customer-perceived value in online customer engagement. Journal of Marketing Management, 32(5-6), 502-525.

Muntinga, D. G., Moorman, M., \& Smit, E. G. (2011). Introducing COBRAs. Exploring motivations for brand-related social media use. International Journal of Advertising, 30(1), 13-46.

Muthén, B. O., \& Muthén, L. K. (2017). Mplus user's guide. $7^{\text {th }}$ ed. Los Angeles, CA: Muthén \& Muthén.

Nunnally, J. C. (1978). Psychometric theory. 2nd ed. New York: McGraw-Hill.

Pansari, A., \& Kumar, V. (2017). Customer engagement: the construct, antecedents, and consequences. Journal of the Academy of Marketing Science, 45(3), 294-311.

Plé, L., \& Chumpitaz Cáceres, R. (2010). Not always co-creation: introducing interactional co-destruction of value in service-dominant logic. Journal of Services Marketing, 24(6), 430-437. 
Ratchford, B. T. (1987). New Insights about the FCB Grid. Journal of Advertising Research, 27(4), 24-38.

Rohrbeck, R., Steinhoff, F., \& Perder, F. (2010). Sourcing innovation from you customer: How multinational enterprises use Web platforms for virtual customer integration. Technology Analysis \& Strategic Management, 22(4), 117-131.

Saarijärvi, H., Kannan, P. K., \& Kuusela, H. (2013). Value co-creation: theoretical approaches and practical implications. European Business Review, 25(1), 6-19.

Sánchez-Fernández, R., \& Ángeles, M. (2007). The concept of perceived value: a systematic review of the research. Marketing Theory, 7(4), 427-451.

Shah, S. (2004). Understanding the Nature of Participation and Coordination in Open and Gated Source Software Development Communities. In Academy of Management Proceedings (pp. B1-B5). New Orleans: Academy of Management.

Sheth, J. N., Newman, B. I., \& Gross B. L. (1991). Why We Buy What We Buy: A Theory of Consumption Values. Journal of Business Research, 22(2), 159-170.

Steiger, J. H. (1990). Structural model evaluation and modification: An interval estimation approach. Multivariate Behavioral Research, 25(2), 173-180.

Talonen, A., Jussila, I., Saarijärvi, H., \& Rintamäki T. (2016). Consumer cooperatives: uncovering the value potential of customer ownership. AMS Review, 6(3-4), 142-156.

Tucker, L. R., \& Lewis, C. (1973). A reliability coefficient for maximum likelihood factor analysis. Psychometrika, 38(1), 1-10.

van Doorn, J., Lemon, K. N., Mittal, V., Nass, S., Pick, D., Pirner, P., \& Verhoef, P. C. (2010). Customer Engagement Behavior: Theoretical Foundations and Research Directions. Journal of Service Research, 13(3), 253-266.

Vargo, S. L. (2008). Customer Integration and Value Creation. Paradigmatic Traps and Perspectives. Journal of Service Research, 11(2), 211-215.

Vargo, S. L., \& Lusch, R. F. (2008). Service-Dominant Logic: Continuing the Evolution. Journal of the Academy of Marketing Science, 36(1), 1-10.

Vargo, S. L., \& Lusch, R. F. (2017). Service-dominant logic 2025. International Journal of Research in Marketing, 34(1), 46-67.

Vaughn, R. (1986). How advertising works: A planning model revisited. Journal of Advertising Research, 26(1), 57-66. 
Verhagen, T., Swen, E., Feldberg, F., \& Merikivi, J. (2015). Benefitting from virtual customer environments: An empirical study of customer engagement. Computers in Human Behavior, 48, 340-357.

Verhoef, P., Reinartz, W., \& Krafft, M. (2010). Customer Engagement as a New Perspective in Customer Management. Journal of Service Research, 13(3), 247-249.

Verleye, K., Gemmel, P., \& Rangarajan, D. (2014). Managing engagement behaviors in a network of customers and stakeholders: evidence from the nursing home sector. Journal of Service Research, 17(1), 68-84.

Vivek, S., Beatty, S., \& Morgan, M. (2012). Customer Engagement: Exploring Customer Relationships beyond Purchase. Journal of Marketing Theory and Practice, 20(2), 127-145.

Vivek, S. D., Beatty, S. E., Dalela, V., \& Morgan, R. M. (2014). A Generalized Multidimensional Scale for Measuring Customer Engagement. Journal of Marketing Theory and Practice, 22(4), 401-420.

Woodruff, R. B., \& Gardial, S. F. (1996). Know Your Customer. New Approaches to Understanding Customer Value and Satisfaction. Oxford: Blackwell.

Zaichkowsky, J. L. (1985). Measuring the Involvement Construct. Journal of Consumer Research, 12(3), 341-352.

\section{Author}

Katarzyna Żyminkowska, Ph.D. (dr hab.)

Associate Professor

Marketing and Entrepreneurship Department

Faculty of Management and Transport

University of Bielsko-Biala

Willowa 2, 43-309 Bielsko-Biala, Poland

kzyminkowska@ath.bielsko.pl 


\section{Appendix 1: Measurement instrument}

Customers' communication ${ }^{\text {a }}$ (based on: Verleye et al., 2014; Muntinga et al., 2011)

Do you exchange the opinions on products, brands or firms in the following ways:

1. I write positive product reviews in the Internet.

2. I upload brand or firm related pictures, films in the Internet.

3. I participate in the recommendation programs.

4. I click "likes" related to brand/firms.

Customer complaints ${ }^{\mathrm{a}}$ (based on: Stauss and Seidel, 2006)

Do you complain about the products or brands in the following ways:

1. I file the formal, written complaint.

2. I provide information verbally if something is wrong with the product during or after purchase.

3. I answer the call centre questions informing them about my dissatisfaction.

4. I answer additional questions while my complaint is proceeded.

Customer collaboration ${ }^{\text {a }}$ (based on: Jakkola and Alexander, 2014; Rohrbeck et al., 2010)

Do you collaborate with brand or firm helping to create solutions in the in the following ways:

1. I participate in surveys concerning my needs and expectations of the products.

2. I vote for the products or brands.

3. I participate infirm or brand contest, e.g. providing the ideas of packages or ads.

4. A attend the events associated with brands or firms.

Hedonic customer value dimension ${ }^{\mathrm{b}}$ (Rohrbeck et al., 2010; Verhagen et al., 2015; Latteman and Robra-Bissantz, 2005)

How important are the following reasons of your engagement in the relations focused on brands or firms?

1. Making contacts with other users.

2. Joining the consumer communities (e.g. brand fans).

3. Being respected by other people. 
Utilitarian customer value dimension ${ }^{\mathrm{b}}$ (Rohrbeck et al., 2010; Verhagen et al., 2015; Latteman and Robra-Bissantz, 2005)

How important are the following reasons of your engagement in the relations focused on brands or firms?

1. Getting a better product.

2. Receiving discounts for next shopping.

3. Receiving the substantial reward.

Coding: a) 1(strongly disagree)-5(strongly agree); b) 1(strongly unimportant)-5(strongly important) 